\title{
Involvement of fat mass and obesity gene (FTO) in the anti-obesity action of Annona muricata Annonaceae: in silico and in vivo studies
}

\author{
Olusola Olalekan Elekofehinti ${ }^{1}$ - Akeem Olalekan Lawal ${ }^{1}$ • Oluwamodupe Cecilia Ejelonu ${ }^{2}$. \\ Olorunfemi Raphael Molehin ${ }^{3} \cdot$ Courage Dele Famusiwa $^{1}$
}

Received: 20 September 2019 / Accepted: 5 January 2020 / Published online: 12 March 2020

(C) Springer Nature Switzerland AG 2020

\begin{abstract}
Background Annona muricata (Annonaceae) known as soursop is a common tropical plant species known for its numerous medicinal properties including obesity. The underlying mechanism of anti-obesity effect of A. muricata was investigated. The fat mass and obesity associated protein (FTO) is a validated potential target for anti-obesity drugs.

Methods The interaction of compounds previously characterized from A. muricata was investigated against FTO using Autodock Vina. Also, modulation of FTO and STAT-3 mRNA expression by A. muricata was investigated in high fat diet induced obese rats (HFDR) using RT-PCR.

Results A significant up-regulation of FTO gene was observed in HFDR when compared to control rats, while administration of A. muricata $(200 \mathrm{mg} / \mathrm{kg})$ significantly $(p<0.05)$ down-regulated FTO gene expression when compared to HFDR group. The effect of obesity on STAT-3 gene expression was also reversed by A. muricata $(200 \mathrm{mg} / \mathrm{kg})$. In silico study revealed annonaine and annonioside $(-9.2 \mathrm{kcal} / \mathrm{mol})$ exhibited the highest binding affinity with $\mathrm{FTO}$, followed by anonaine and isolaureline ( $-8.6 \mathrm{kcal} / \mathrm{mol})$. Arg-96 is a critical amino acid enhancing anonaine, isolaureline-FTO binding.

Conclusion This study suggests the possible anti-obesity mechanism of A. muricata is via down-regulation of FTO with concomitant up-regulation of STAT-3 genes. This study confirmed the use of this plant in the management of obesity and the probable compounds responsible for its antiobesity effect are annonaine and annonioside.
\end{abstract}

Keywords Annona muricata $\cdot$ Molecular docking $\cdot$ FTO and STAT-3 genes $\cdot$ Obesity

\section{Introduction}

Obesity refers to abnormal or excessive fat accumulation that presents a risk to health. More than 1.5 billion adults above the 20 age mark are found to be overweight out of which 200 million men and about 300 million women obese. In the twenty-first century, excessive body mass and obesity are common health difficulties in contemporary society, predominantly in developed

Olusola Olalekan Elekofehinti

ooekofehinti@futa.edu.ng; sola_eleko@yahoo.com

1 Bioinformatics and Molecular Biology Unit, Department of Biochemistry, Federal University of Technology Akure, P.M.B 704, Akure, Ondo State, Nigeria

2 Department of Biochemistry, Ondo State University of Science and Technology, Okitipupa, Ondo State, Nigeria

3 Department of Biochemistry, Faculty of Science, Ekiti State University, P.M.B. 5363, Ado-Ekiti 360001, Nigeria nations. Obesity is increasingly linked to several diseases and metabolic complications like cardiovascular diseases, diabetes and cancer [1]. Environmental and genetic factors have been linked to predispose individuals to increase risk of obesity. Obesity, an impending global pandemic, is not being effectively controlled by current measures such as lifestyle modifications, bariatric surgery or available medications. Its toll on health and economy compels us to look for more effective measures [2]. Development of anti-obesity drugs has often been riddled with problems in the past. Some of the recently approved drugs for pharmacotherapy of obesity have been lorcaserin, phentermine/ topiramate and naltrexone/ bupropion combinations. Although many anti-obesity drugs have been in use but due to several side effects newer and safer alternatives are highly sought after [3].

Advances in molecular technology have enhanced development of new drugs delineating new pathways in the pathophysiology of obesity and have led to the development of new drug targets like fat mass and obesity associated protein (FTO). FTO is currently a potential target for anti-obesity 
Table 1 Diet composition for normal control and high fat diet fed rats

\begin{tabular}{lll}
\hline & Normal control diet $(\mathrm{g} / \mathrm{kg})$ & High fat diet $(\mathrm{g} / \mathrm{kg})$ \\
\hline Skimmed milk & 500 & 500 \\
Lard & - & 300 \\
Rice bran & 200 & 90 \\
Corn starch & 160 & 70 \\
Premix & 40 & 40 \\
Groundnut oil & 100 & - \\
\hline
\end{tabular}

Skimmed milk contains $360 \mathrm{~g} \mathrm{~kg}^{-1}$ protein; mineral and vitamin premix $\left(10 \mathrm{~g} \mathrm{~kg}^{-1}\right)$ contains 3200 i.u. vitamin A, 600 i.u vitamin $\mathrm{D}_{3}, 2.8 \mathrm{mg}$ vitamin E, $0.6 \mathrm{mg}$ vitamin $\mathrm{K}_{3}, 0.8 \mathrm{mg}$ vitamin $\mathrm{B}_{1}, 1 \mathrm{mg}$ vitamin $\mathrm{B}_{2}, 6 \mathrm{mg}$ niacin, $2.2 \mathrm{mg}$ pantothenic acid, $0.8 \mathrm{mg}$ vitamin $\mathrm{B}_{6}, 0.004 \mathrm{mg}$ vitamin $\mathrm{B}_{12}, 0.2 \mathrm{mg}$ folic acid, $0.1 \mathrm{mg}$ biotin $\mathrm{H}_{2}, 70 \mathrm{mg}$ choline chloride, $0.08 \mathrm{mg}$ cobalt, $1.2 \mathrm{mg}$ copper, $0.4 \mathrm{mg}$ iodine, $8.4 \mathrm{mg}$ iron, $16 \mathrm{mg}$ manganese, $0.08 \mathrm{mg}$ selenium, $12.4 \mathrm{mg}$ zinc, $0.5 \mathrm{mg}$ antioxidant and lard contains $99 \%$ fat

drugs [4] and one of the salient genes implicated in obesity [5]. It has also linked to obesity-related ailments, like cardiovascular diseases [1], hypertension [6], polycystic ovary syndrome [7], and type II diabetes [8]. The Signal transducer and activator transcription gene (STAT-3) function saliently in energy metabolism and is highly expressed in manifold metabolic tissues. It is an associate of the STAT protein family, which upon phosphorylation in response to growth factors and different cytokines is translocated to the nucleus of the cell in other to function as a transcription factors [9]. Phosphorylated STAT3 induces expression of SOCS3, which acts as a feedback inhibitor of the leptin signaling pathway $[10,11]$ and targeted deletion of STAT3 from neural tissue of mice, results in obesity [12].

Increase in the consumption of plants have been proven effective in weight and obesity management [13]. Annona muricata is a member of the Annonaceae family and it is a fruit-bearing tree with a lengthy antiquity of folkloric use. A. muricata, also well-known as soursop, graviola and guanabana, is a perennial plant which is mostly found in tropical and subtropical sections of the world [14]. The fruits of A. muricata are expansively used to make syrups, candies, beverages, ice creams as well as shakes. An extensive array of ethnomedicinal activities is underwritten of different parts of A. muricata, and home-grown societies in Africa and South America lengthily use this plant in their folk medicine $[15,16]$. Abundant studies have substantiated these therapeutic activities comprising anticancer, anticonvulsant, anti-arthritic, antiparasitic [14, 16], antimalarial, hepatoprotective and antidiabetic activities $[17,18]$. Extensive phytochemical assessments on various parts of A. muricata plant have revealed the presence of different phytoconstituents, which include alkaloids, phenolics, megastigmanes, flavonol triglycosides, cyclopeptides and essential oils amist others [14, 19].

The anti-obesity potential of this plant have been well documented $[20,21]$ but there is dearth of information on the likely mechanism of anti-obesity action. Hence, this study aims at investigating the involvement of fat mass and obesity gene (FTO) and STAT-3 in the anti-obesity action of Annona muricata Annonaceae using both in silico and in vivo approach.

\section{Materials and methods}

\section{In silico experiment}

\section{Ligand preparation and docking scoring}

Compounds previously characterized from A. muricata were retrieved from literatures and drawn using ChemAxon suite (https://www.chemaxon.com). The structures were optimized for docking using Open Babel (http://openbabel. org). The compounds were docked into the active sites of FTO $(\mathrm{PDB}=3 \mathrm{lfm})$ using Autodock Vina. The procedure was carried out by considering the flexibility of the ligand such that all rotational bonds were set free and the estimated binding energies for the best pose were recorded.

\section{Plant materials}

The leaves of A. muricata were collected from the horticulture garden of The Federal University of Technology Akure, Ondo State. The leaves were air dried, pulverized and stored at room temperature in air tight polythene bag prior to use. Five grams each of the leaves of A. muricata fruit were weighed into the extraction bottle and two hundred milliliters of distilled water was added to the bottle and left for $24 \mathrm{~h}$ to allow for extraction. Thereafter, the solution was filtered using a Whatman filter

Table 2 Primer sets for the gene expression

\begin{tabular}{llll}
\hline Gene & Forward primers & Reverse primers & Accession number \\
\hline FTO & 5'-CTCTACCAGCACAGCAGAAA-3' & 5-' CAAAGGGCAGAGGCATAGAA-3' & BC168239.1 \\
STAT-3 & 5-' - CACCCATAGTGAGCCCTTGGA-3' & 5' $^{\prime}$ - TGAGTGCAGTGACCAGGACAGA-3' & NM_012747.2 \\
GAPDH & 5'- AGACAGCCGCATCTTCTTGT-3 & 5' $^{\prime}$ CTTGCCGTGGGTAGAGTCAT -3' & X02231.1 \\
\hline
\end{tabular}


Table 3 Binding affinity of $A$. muricata phytochemicals with fat mass and obesity associated gene (FTO)

\begin{tabular}{|c|c|c|}
\hline 1 & Phytochemicals & Binding Energy $(\mathrm{Kcal} / \mathrm{mol})$ \\
\hline 2 & Acetogenin & -7.9 \\
\hline 3 & Annohexocin & -6.3 \\
\hline 4 & Annoionol A & -5.7 \\
\hline 5 & Annoionol B & -6.7 \\
\hline 6 & Annoionol C & -6.3 \\
\hline 7 & Annomuricin A & -6.9 \\
\hline 8 & Annnomuricin B & -6.7 \\
\hline 9 & Annomuricin E & -7.1 \\
\hline 10 & Annomutaicin & -7.0 \\
\hline 11 & Annonacin & -7.3 \\
\hline 12 & Annonacini one & -6.9 \\
\hline 13 & Annonacin A & -7.2 \\
\hline 14 & Annonaine & -9.2 \\
\hline 15 & Annonioside & -9.2 \\
\hline 16 & Annopentocin A & -6.4 \\
\hline 17 & Annopentocin B & -7.3 \\
\hline 18 & Annoreticuin 9one & -7.0 \\
\hline 19 & Anomricine & -6.8 \\
\hline 20 & Anomurine & -6.9 \\
\hline 21 & Anonacin & -6.9 \\
\hline 22 & Anonaine & -8.6 \\
\hline 23 & arianaCIN & -6.7 \\
\hline 24 & Asimicin & -6.9 \\
\hline 25 & Asimilobine & -7.2 \\
\hline 26 & atherspeminine & -7.8 \\
\hline 27 & blumenol C & -5.9 \\
\hline 28 & Bullaticin & -7.6 \\
\hline 29 & CIS - annonaci10one & -7.1 \\
\hline 30 & CIS - annoreticuin & -7.0 \\
\hline 31 & CIS - goniothalamicin & -7.1 \\
\hline 32 & CIS - panatellin & -6.3 \\
\hline 33 & CIS - reticulacacin 10 one & -6.4 \\
\hline 34 & CIS - solamin & -6.2 \\
\hline 35 & CIS - uvariamic iv & -6.5 \\
\hline 36 & CIS - uvariamicin .1 & -6.4 \\
\hline 37 & Citroride A & -8.0 \\
\hline 38 & Coclaurine & -6.9 \\
\hline 39 & Cohibin A & -6.1 \\
\hline 40 & Cohibin B & -5.7 \\
\hline 41 & Corexamine & -8.1 \\
\hline 42 & Corposolin & -6.3 \\
\hline 43 & Corrosolone & -6.4 \\
\hline 44 & $\mathrm{Cs}$ - reticulatacin & -6.7 \\
\hline 45 & Epiloliolide & -5.6 \\
\hline 46 & Epomuricerin B & -7.2 \\
\hline 47 & Epomuricerin A & -6.5 \\
\hline 48 & Epoxymurin A & -6.7 \\
\hline 49 & Epoxymurin B & -5.6 \\
\hline
\end{tabular}

Table 3 (continued)

\begin{tabular}{|c|c|c|}
\hline 1 & Phytochemicals & Binding Energy $(\mathrm{Kcal} / \mathrm{mol})$ \\
\hline 50 & gigantetrocin $\mathrm{A}$ & -6.4 \\
\hline 51 & gigantetronenin & -7.5 \\
\hline 52 & Isoannonacin & -7.4 \\
\hline 53 & Isolaureline & -8.6 \\
\hline 54 & Javoricin & -6.6 \\
\hline 55 & Kaemferol 3 -o-rutinoside & -8.1 \\
\hline 56 & Monteeristin & -6.4 \\
\hline 57 & Muricapentocin & -7.4 \\
\hline 58 & Muricatacin & -5.9 \\
\hline 59 & Muricatetrocin A & -6.9 \\
\hline 60 & Muricatocin A & -6.8 \\
\hline 61 & Muricatocin B & -7.0 \\
\hline 62 & Muricoreacin & -6.7 \\
\hline 63 & Murihexocin A & -6.5 \\
\hline 64 & Murihexocin B & -6.4 \\
\hline 65 & Normuciferine & -8.0 \\
\hline 66 & Reticuline & -7.3 \\
\hline 67 & Roseoside & -7.6 \\
\hline 68 & Rutin & -8.5 \\
\hline 69 & Sabadelin & -6.3 \\
\hline 70 & Stepharine & -7.1 \\
\hline 71 & Trilobacin & -7.4 \\
\hline 72 & Xylopine & -8.4 \\
\hline
\end{tabular}

paper. The extract was stored air tight in a refrigerator until required for use.

\section{In vivo study}

Male Wistar rats (18 rats), 6 weeks old, weighting 125 $170 \mathrm{~g}$, were selected and divided into 3 groups $(n=6)$. They were allowed to acclimatize to experimental condition for two weeks. They were housed in clean cages and maintained under standard laboratory conditions (temperature $25^{`} 2 \mathrm{C}$ with dark/light cycle 12/12 h). Control group was $100 \%$ fed normal diet, and the other two groups were fed with with high fat diet with feed formulation (Table 1) as previously described [22]. Group I: normal rats and group II: negative control (obese untreated rats) were administered with $0.5 \mathrm{ml}$ distilled water, group III: were obese rats administered with $200 \mathrm{mg} / \mathrm{kg}$ A. muricata aqueous extract for 21 days. The principles of Laboratory Animal care (NIH Publication 85-93, revised 1985) [23] were followed throughout the duration of the experiment.

\section{Gene expression}

Total RNA was isolated from the rat pancreas with TRIzol Reagent (ThermoFisher Scientific) and DNA contaminant was removed following DNAse I treatment. The RNA was quantified 
Table 4 Lead compounds from A. muricata and amino acid within the active site of FTO with hydrogen bond and hydrophobic interactions

\begin{tabular}{|c|c|c|c|}
\hline & $\begin{array}{l}\text { A. muricata } \\
\text { compounds }\end{array}$ & Hydrogen bond & Hydrophobic interaction \\
\hline 1 & Annonioside & 5 (Arg-96, Arg-316, His-307, His231, Ser-229) & $\begin{array}{l}12 \text { (Tyr-320, Tyr-295, Asn-205, Asp-233, Val-244, Val-309, Tyr-108, Leu-109, } \\
\text { Val-228, Pro-93, Val-94, Ala-227) }\end{array}$ \\
\hline 2 & Annonaine & 1 (Arg-96) & 8 (Tyr-108, Val-228, Arg-322, Asp-233, Leu-109, Glu-234, His-231, His-232 \\
\hline 3 & Anonaine & 1 (Tyr-108) & 7 (Tyr-106, Asp-233, Glu-234, His-231, His-232, Leu-109, Arg-322) \\
\hline 4 & Citroside A & 5 (His-232, Glu-234, Arg-96, Tyr-106, Arg-322) & $\begin{array}{l}11 \text { (Ala-227, Val-228, Val-94, Thr-92, Ser-229, Ile-85, Leu-109, His-231, Tyr-108, } \\
\text { Leu-203, Asp-233) }\end{array}$ \\
\hline 5 & Corexamine & 2 (Ala-227, Arg-96) & 9 (Pro-93, Val-228, Leu-109, His-231, Tyr-108, Tyr-106, Glu-234, Asp-233, Ser-229) \\
\hline 6 & Isolaureline & Arg-96 & 9 (Val-228, Tyr-108, His-231, Ile-85, Leu-109, Pro-93, Ser-229, Val-94 \\
\hline 7 & Normuciferine & Nil & $\begin{array}{l}\text { His-232, Glu-234, Asp-233, Tyr-106, His-231, Tyr-108, Arg-96, Pro-93, Val-94, } \\
\text { Val-228, Leu-109 }\end{array}$ \\
\hline 8 & Rutin & $\begin{array}{l}7 \text { (Tyr-295, Asp-233, Asn-205, Ser-318, His-231, } \\
\text { Trp-230, Ser-229) }\end{array}$ & $\begin{array}{l}13 \text { (Leu-109, Ile-85, Tyr-108, Pro-93, Ala-227, Val-228, Val-94, Arg-96, Val-309, } \\
\text { Arg-316, Thr-320, Val-224, His-307) }\end{array}$ \\
\hline
\end{tabular}

and the purity confirmed spectrophometrically (A and E Lab UK) at $260 \mathrm{~nm}$ and $280 \mathrm{~nm}$. The RNA was converted to cDNA using ProtoScript First Strand cDNA Synthesis Kit (NEB). PCR amplification was done using OneTaq® 2X Master Mix (NEB) using the following primer set (Table 2).

\section{Polymerase chain reaction (PCR)}

The assay was performed using an optimization Template (cDNA) $5 \mu \mathrm{l}$, nucleas-free water $3.5 \mu \mathrm{l}$, forward primers $2 \mu \mathrm{l}$ and reverse primers $2 \mu \mathrm{l}$ and master mix $2 \mu$ l (Table 1), Reverse Transcription-PCR reaction was performed in a $15.0 \mu$ final volume. Amplification conditions were: $94{ }^{\circ} \mathrm{C}$ pre-denaturation for $5 \mathrm{~min}, 94^{\circ} \mathrm{C}$ for $30 \mathrm{~s}$, annealing $55^{\circ} \mathrm{C}$ for $30 \mathrm{~s}$ and Extension $72{ }^{\circ} \mathrm{C}$ for $30 \mathrm{~s}$ and then $5 \mathrm{~min}$ at $72{ }^{\circ} \mathrm{C}$ by 30 cycles.

\section{Gel electrophoresis}

Assessment of Polymerase Chain Reaction products (amplicons) were electrophoresed in $0.2 \%$ of agarose gel using $0.5 \times \mathrm{TBE}$ buffer (2.6 $\mathrm{g}$ of Tris base, $5 \mathrm{~g}$ of Tris boric acid and $2 \mathrm{ml}$ of $0.5 \mathrm{M}$ EDTA and adjusted to $\mathrm{pH} 8.3$ with the sodium hydroxide pellet) with $3 \mu \mathrm{l}$ EZ-vision (VWR Life Science). The expression product was visualized as bands by Blue-light-transilluminator. The intensities of the bands from agarose gel electrophoresiswere was quantified densitometrically using ImageJ software. Representative snapshot of reverse transcription polymerase chain reaction-agarose gel electrophoresis data was plotted as a bar graph.

\section{Statistical analysis}

Data collected were analyzed using one way analysis of variance (ANOVA) using SPSS version 20 and were expressed as mean \pm SEM. Duncan's multiple ranges was used to separate the means. Differences were considered to be statistically significant when ( $p$ $<0.05)$. Graphpad prism version 7.04 was used to plot the graph. The intensities of the bands form agarose gel electrophoresis were quantified densitometrically using ImageJ software. Pymol was used to visualize the protein interaction while Ligplot was used to analyse the protein-ligand binding interaction.

\section{Results}

\section{Identification FTO as A. muricata-derived compounds target}

A library of phytocompounds from $A$. muricata based on previous studies of isolation and structural elucidation was created and maintained in our laboratory. Molecular docking analysis showed that A. muricata-derived compounds showed good affinity (Table 3) for FTO ( -5.6 to $-9.2 \mathrm{kcal} / \mathrm{mol})$. Annonaine and annonioside showed the lowest binding energy for FTO both with binding energy of $-9.2 \mathrm{kcal} / \mathrm{mol}$, while epiloliolide showed highest binding energy $(-5.6 \mathrm{kcal} / \mathrm{mol})$ for FTO. Those with binding affinity ranging from -8.0 to $-9.2 \mathrm{kcal} / \mathrm{mol}$ are presented in Table 4. The number of hydrogen bonds and hydrophobic interactions together with amino acid residues critical to ligand binding are also shown (Table 4). The binding pose (Fig. 1) of any compound at the binding site of any protein determines the amino acid residues it will interact with as well as binding affinity. The binding pose of annonioside and annonaine (phyto-compounds in A. muricata) with lowest binding affinity with FTO is shown in Fig. 1 Arg-96 is a critical amino acid residue critical to both annonioside and annonaine binding to FTO.

\section{A. muricata administration modulates the expression of FTO and STAT-3 genes in HFD rats}

In the present study, high fat diet up-regulated the expression $(p<0.05)$ of FTO gene relative to normal control rats while administration of $A$. muricata $(200 \mathrm{mg} / \mathrm{kg})$ significantly down-regulated $(p<0.05)$ FTO gene expression relative to high fat diet rats (Fig. 2). Conversely, induction of obesity in rats by HFD significantly down-regulated the expression of 


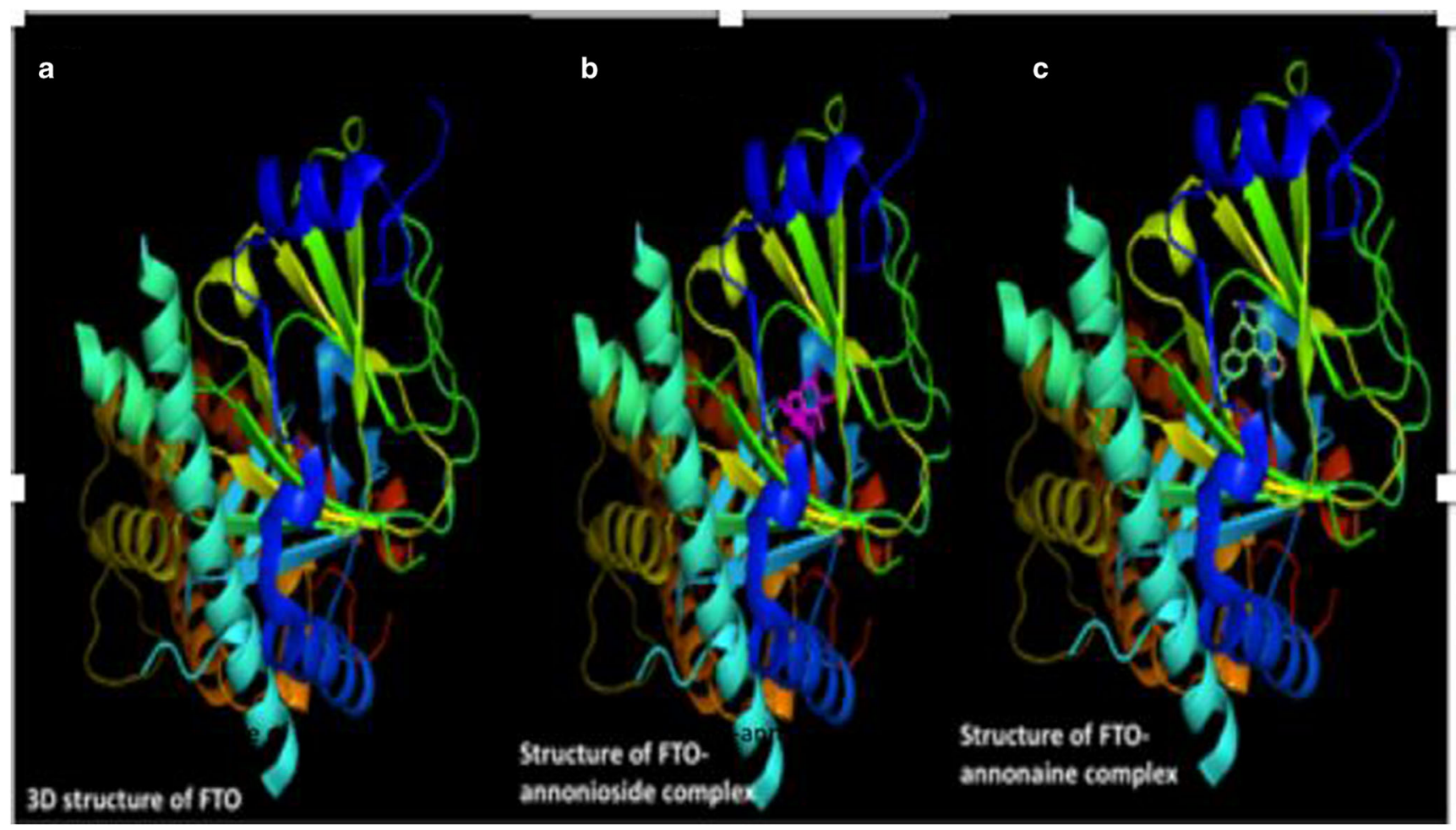

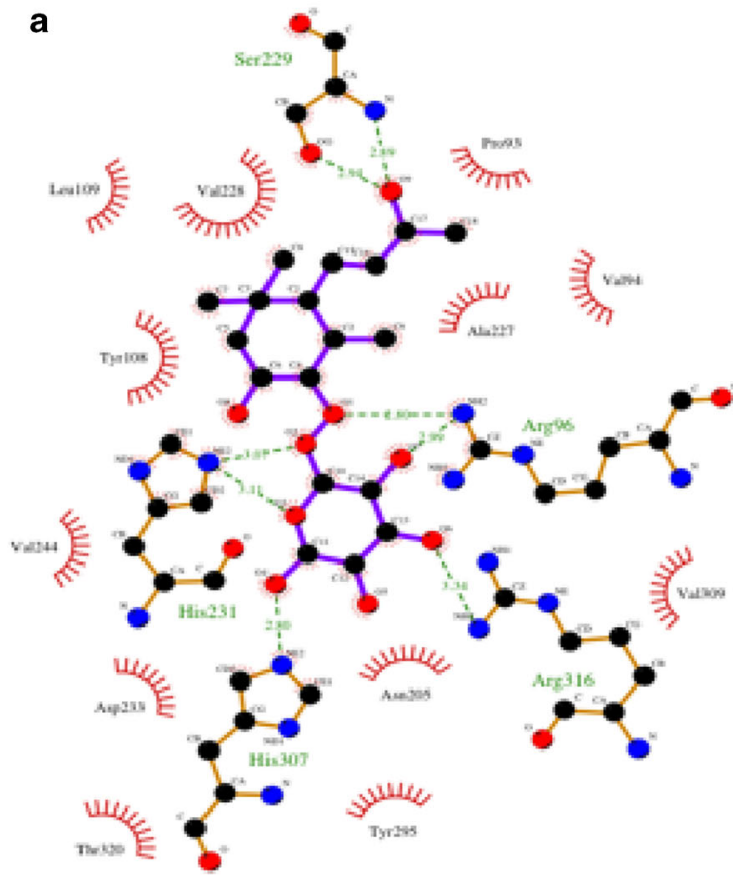

FTOAnnonioiside b

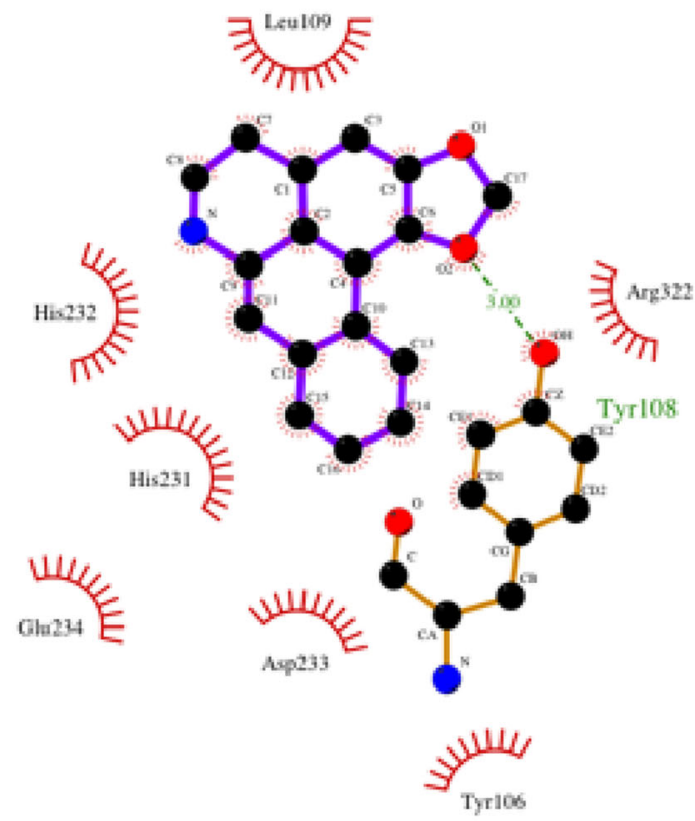

FTOAnonaine

Fig. 1 a 3D structure of FTO (A), FTO-annonioside complex (B) and FTO-annonaine complex (C). b. 2D illustration of FTO-annonioside complex (A) and FTO-annonaine complex (B) revealing interacting amino acids enhancing ligand binding

STAT-3 gene relative to normal control rats while treatment of obese rats with $200 \mathrm{mg} / \mathrm{kg} \mathrm{A}$. muricata significantly up- regulated the expression of STAT-3 gene relative to HFD group (Fig. 3). 


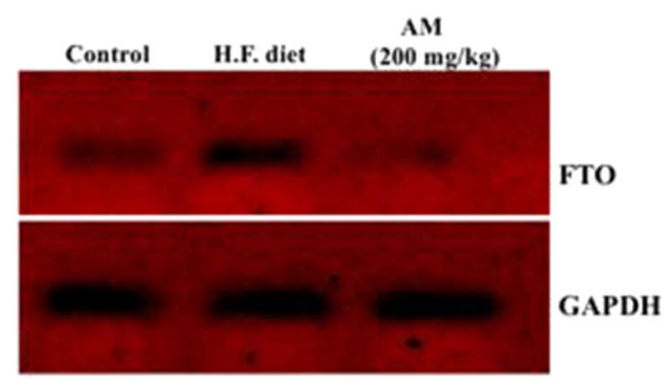

Fig. 2 Relative expression of fat mass and obesity associated gene (FTO) in high fat diet induced obese rat treated with A. muricata extract (200 mg/kg). * represent statistical difference $(p<0.05)$ relative to control while \# represents statistical difference $(\mathrm{p}<0.05)$ relative to HFD

\section{Discussion}

Over the past century, phytochemicals in plants have been a crucial channel for pharmaceutical innovation and significant scientific interest in the biological properties of these substances [24]. Annona muricata is highly abundant in Nigeria

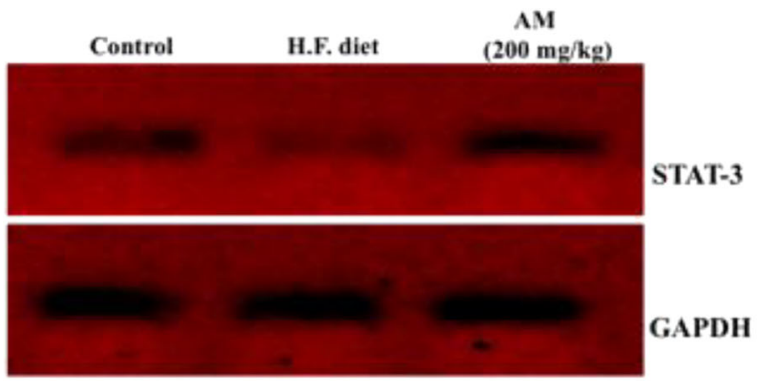

and commonly used in the management of cancer, diabetes and obesity. Although the anti-obesity effect of this plant have been documented but the underlying mechanism is still very unclear. In the current study, we identified the molecular target of A. muricata-derived compounds as fat mass and obesity associated gene (FTO). FTO is the first gene associated with

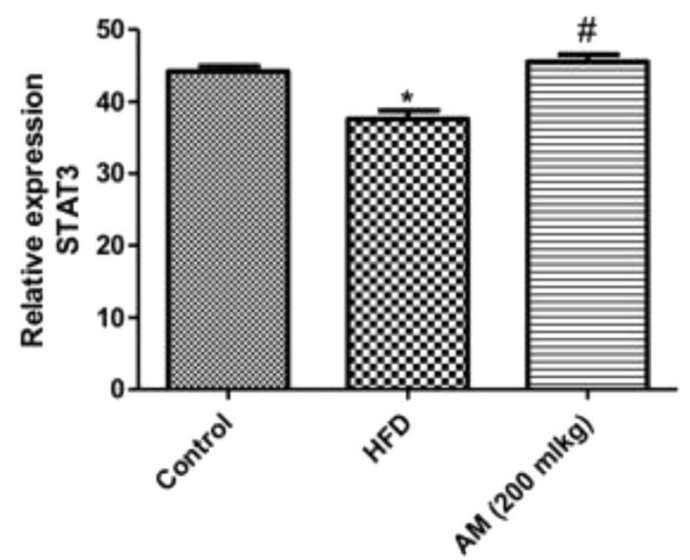

Fig. 3 Relative expression of Signal transducer and activator of transcription 3 gene (STAT-3) in high fat diet induced obese rat treated with A. muricata extract $(200 \mathrm{mg} / \mathrm{kg})$. * represent statistical difference $(\mathrm{p}<0.05)$ relative to control while \# represents statistical difference $(\mathrm{p}<0.05)$ relative to HFD 
body mass index (BMI) and risk for diabetes [25]. FTO is highly expressed in the brain and pancreas, and is involved in regulating dietary intake and energy expenditure [26]. High expression of FTO gene has been reported in obesity and down-regulation of FTO gene expression seems a logical approach to the management of obesity [27].

In this study, phytochemicals previously characterized from Annona muricata maintained at the Computational and Molecular Biology Unit, Department of Biochemistry, FUTA were docked into the crystal structure of human fat mass and obesity associated protein (FTO) using Autodock Vina. Annonaine and annonioside $(-9.2 \mathrm{kcal} / \mathrm{mol})$, anonaine and isolaureline $(-8.6 \mathrm{kcal} / \mathrm{mol})$, rutin $(8.5 \mathrm{kcal} / \mathrm{mol})$, xylopine and corexamine $(-8.1 \mathrm{kcal} / \mathrm{mol})$, normuciferine and citroside A $(-8.0 \mathrm{kcal} / \mathrm{mol})$ ranked best in binding affinity with FTO Table 3 out of 72 compounds documented for A. muricata (Table 3). The compounds interacted within the core of the protein (Fig. 1a) forming hydrogen bonds and hydrophobic interaction with amino acids within the active site of FTO (Fig. 1b Table 4). The eight (8) lead compounds exhibited higher affinity for FTO than the standard drug; (1-[(2R,4S,5R) -4- hydroxy-5-(hydroxymethyl)oxolan-2-yl]3,5-dimethyl-2,3- dihydropyrimidine-2,4-dione $(-6.7 \mathrm{kcal} /$ mol) co-crystallized with FTO. Arg-96 is a critical amino acid responsible for Annona muricata-derived compounds with FTO (Table 4).

In order to further investigate the anti-obesity effect of Annona muricata, an in vivo study was conducted to determine the effect of the plant extract on FTO gene expression in high fat diet induced obesity in rats. The expression of FTO gene was up-regulated in high fat diet induce obese rats (HFD) when compared to the control group (Fig. 2). This result was consistent with previously documented literature [5, 28-30]. Treatment of obese rats with Annona muricata $(200 \mathrm{mg} / \mathrm{kg}$ ) for 21 days showed significant down-regulation of FTO gene expression when compared to obese untreated rats. This was probably possible due to the vast enormity of phytochemicals in A. muricata extract especially the annonioside and annonaine that showed highest binding interaction with FTO from docking experiment relative to other phytochemicals found in A. muricata (Table 4) The down-regulation of FTO by phytocompounds in Annona muricata is an indication that they are inhibitors of FTO. The transformation of obese rats to normal after 21 days (data not shown) of treatment with A. muricata leave was as a result of reduced food intake as global overexpression of FTO has been known to cause obesity due to increased food intake [31].

The mRNA expression of STAT- 3 gene was downregulated in HFD rats when compared with the control group (Fig. 3). This result was in tandem with that which was reported by Ma et al. [32]. STAT3 has been implicated in the control of neuron/glial differentiation and leptin-mediated energy homeostasis and deletion of STAT- 3 has been linked with insulin resistance and obesity [26]. Treatment of HFD rats with A. muricata extract $(200 \mathrm{mg} / \mathrm{kg})$ significantly $(p<0.05)$ upregulated the expression of STAT-3 gene when compared with the HFDR group (Fig. 3), the leptin signaling pathway leading to reduction in food intake by the rats thereby reducing the weight of obese rats.

The results of the in vivo and in silico study suggests that A. muricata extract possess excellent anti-obesity property and its mechanism of action is probably through the downregulation of FTO and up-regulation of STAT- 3 genes leading to reduction in food intake. The molecular docking result provides a valuable starting point for subsequent design of new potential anti-obesity drugs. More studies (in-silico, in-vitro and in-vivo) on FTO genes in relation to adipogenesis is essential to further understand the role of this gene in obesity.

\section{Conclusion}

Based on the in silico analysis, we suggest all eight candidate compounds listed in Table 4 as potential FTO inhibitors that hinder the protein's demethylation functions.

\section{Compliance with ethical standards}

Animal ethics All of the animals received humane care according to the criteria outline in the Guide for the Care and the Use of Laboratory Animals prepared by the National Academy Science and published by the National Institute of Health (USA). The ethic regulations have been followed in accordance with national and institutional guidelines for the protection of animals' welfare during experiments. The experiment was carried out at the Bioinformatics and Molecular Biology Laboratory, Department of Biochemistry, Federal University of Technology, Akure, Ondo State, Nigeria.

Conflict of interest The authors declare that they have no conflict of interest.

\section{References}

1. Chang PC, Wang JD, Lee MM, Chang SS, Tsai TY, Chang KW, et al. Lose weight with traditional Chinese medicine? Potential suppression of fat mass and obesity-associated protein. J Biomolecular Structure and Dynamics. 2011;29(3):471-83.

2. Dina C, Meyre D, Gallina S, Durand E, Körner A, Jacobson P, et al. Variation in FTO contributes to childhood obesity and severe adult obesity. Nat Genet. 2007;39(6):724-6.

3. Tung YL, Yeo GS, O'Rahilly S, Coll AP. Obesity and FTO: changing focus at a complex locus. Cell Metab. 2014;20(5):710-8.

4. Yang Q, Xiao T, Guo J, Su Z. Complex relationships between obesity and fat mass and obesity locus. Int J Biol Sci. 2017;13: 615-29.

5. Tews D, Fischer-Posovszky P, Wabitsch M. Regulation of FTO and FTM expression during human preadipocyte differentiation. Hormone and metabolic Res. 2011;43(01):17-21.

6. Timpson NJ, Harbord R, Davey-Smith G, Zacho J, TybjærgHansen A, Nordestgaard B. G.. does greater adiposity increase 
blood pressure and hypertension risk? Mendelian randomization using the FTO/MC4R genotype. Hypertension. 2009;54(1):84-90.

7. Yan Q, Hong J, Gu W, Zhang Y, Liu Q, Su Y, et al. Association of the common rs 9939609 variant of FTO gene with polycystic ovary syndrome in Chinese women. Endocrine. 2009;36(3):377-82.

8. Vadakedath S, Kandi V, Pinnelli VBK, Godishala V. A review of signaling pathways and the genetics involved in the development of type 2 diabetes: investigating the possibility of a vaccine and therapeutic interventions to prevent diabetes. Am J of Clin Med Res. 2018;6(2):24-34.

9. Benito C, Davis CM, Gomez-Sanchez JA, Turmaine M, Meijer D, Poli V, et al. STAT3 controls the long-term survival and phenotype of repair Schwann cells during nerve regeneration. J Neurosci. 2017;37(16):4255-69.

10. Ibars M, Ardid-Ruiz A, Suárez M, Muguerza B, Bladé C, Aragonès G. Proanthocyanidins potentiate hypothalamic leptin/STAT3 signalling and Pomc gene expression in rats with diet-induced obesity. Int J of Obesity. 2017;41(1):129.

11. Chen Y, Wu R, Chen HZ, Xiao Q, Wang WJ, He JP, et al. Enhancement of hypothalamic STAT3 acetylation by nuclear receptor Nur77 dictates leptin sensitivity. Diabetes. 2015;64(6):2069-81.

12. Gurzov EN, Stanley WJ, Pappas EG, Thomas HE, Gough DJ. The JAK/STAT pathway in obesity and diabetes. FEBS J. 2016;283: 3002-15.

13. Chandrasekarah CV, Vijayalaksmi MA, Prakash K, Bansal VS, Meenakshi J, Amit A. Herbal approach for obesity management. Am J Plant Sci. 2012;3:1003-14.

14. Gavamukulya Y, Abou-Elella F, Wamunyokoli F, AEl-Shemy H. Phytochemical screening, anti-oxidant activity and in vitro anticancer potential of ethanolic and water leaves extracts of Annona muricata (Graviola). Asian Pac J Trop Med. 2014;7:S355-63.

15. Adewole S, Ojewole J. Protective effects of Annona muricata Linn. (Annonaceae) leaf aqueous extract on serum lipid profiles and oxidative stress in hepatocytes of streptozotocin-treated diabetic rats. Afr J Trad Compl Alternat Med. 2009;6:30-41.

16. Paul J, Gnanam R. M Jayadeepa R, Arul L. anti-cancer activity on Graviola, an exciting medicinal plant extract vs various cancer cell lines and a detailed computational study on its potent anticancerous leads. Current Topics in Med Chem. 2013;13(14): 1666-73.

17. Ishola IO, Awodele O, Olusayero AM, Ochieng CO. Mechanisms of analgesic and anti-inflammatory properties of Annona muricata Linn. (Annonaceae) fruit extract in rodents. J Medicinal Food. 2014;17(12):1375-82.

18. Asare GA, Afriyie D, Ngala RA, Abutiate H, Doku D, Mahmood SA, et al. Antiproliferative activity of aqueous leaf extract of Annona muricata L. on the prostate, BPH-1 cells, and some target genes. Integ Cancer Therapies. 2015;14(1):65-74.

19. Yang C, Gundala SR, Mukkavilli R, Vangala S, Reid MD, Aneja R. Synergistic interactions among flavonoids and acetogenins in Graviola (Annona muricata) leaves confer protection against prostate cancer. Carcinogenesis. 2015;36(6):656-65.
20. Sasso S, Sampaio E, Souza PC, Santana LF, Cardoso CAL, Alves FM, et al. Use of an extract of Annona muricata Linn to prevent high-fat diet induced metabolic disorders in C57BL/6 mice. Nutrient. 2019;11. https://doi.org/10.3390/nu11071509.

21. Coria-Tellez AV, Montalvo-Gonzalez E, Yahia EM, ObledoVazquez EN. Annona Musicata: a comprehensive review on its traditional medicinal uses, phytochemical, pharmacological activities, mechanisms of action and toxicity. Arab J Chem. 2018;11: 662-91.

22. Adefegha SA, Oboh G, Adefegha OM, Boligon AA, Athayde ML. Antihyperglycemic, hypolipidemic, hepatoprotective and antioxidative effects of dietary clove (Szyzgium aromaticum) bud powder in a high fat diet/streptozotocin-induced diabetes rat model. J Sci Food and Agric. 2014;94:2726-37.

23. NIH Publication 85-93, revised 1985).

24. Moghadamtousi S, Goh B, Chan C, Shabab T, Kadir H. Biological activities and phytochemicals of Swietenia macrophylla king. Molecules. 2013;18(9):10465-83.

25. Loos RJ, Yeo GS. The bigger picture of FTO - the first GWASidentified obesity gene. Nat Rev Endocrinol. 2014;10(1):51-61.

26. Gao Q, Wolfgang MJ, Neschen S, Morino K, Horvath TL, Shulman GI, et al. Disruption of neural signal transducer and activator of transcription 3 causes obesity, diabetes, infertility and thermal dysregulation. Proceedings of the national Academy of Sciences (USA). https://doi.org/10.1073/pnas.0303992101.

27. Kalantari N, Doaei S, Keshavarz-Mohammadi N, Gholamalizadeh M, Pazan N. Review of studies on the fat mass and obesityassociated gene interactions with environmental factors affecting on obesity and its impact on lifestyle interventions. Area Atheroscler. 2016;12:281-90.

28. Aik W, Demetriades M, Hamdan MK, Bagg EA, Yeoh KK, Lejeune $\mathrm{C}$, et al. Structural basis for inhibition of the fat mass and obesity associated protein (FTO). J Med Chem. 2013;56(9):36808.

29. Claussnitzer M, Dankel SN, Kim KH, Quon G, Meuleman W, Haugen C, et al. FTO obesity variant circuitry and adipocyte browning in humans. New Eng J Med. 2015;373(10):895-907.

30. Padariya M, Kalathiya U. Structure-based design and evaluation of novel N-phenyl-1H-indol-2-amine derivatives for fat mass and obesity-associated (FTO) protein inhibition. Computational Biol Chem. 2016;64:414-25.

31. Hess ME, Bruning JC. The fat mass and obesity-associated (FTO) gene: obesity and beyond? Molecular Basis of Disease. 1842;2014: 2039-47.

32. Ma Z, Wang G, Chen X, Ou Z, Zou F. Association of STAT3 common variations with obesity and hypertriglyceridemia: protective and contributive effects. Int J Molecular Sci. 2014;15(7): 12258-69.

Publisher's note Springer Nature remains neutral with regard to jurisdictional claims in published maps and institutional affiliations. 